\title{
In dulci iubilo
}

\section{Martin Luthers juleprædikener i lyset af den kirkelige tradition}

\author{
Lektor, lic.theol. \\ Ninna Jørgensen
}

\begin{abstract}
Luther's Christmas sermons 1525-1530 constitute an identifiable entity. In his yearly efforts to present the "old" announcement to his congregation, he uses a set structure. He retells Luke's gloomy birth narrative from a historical point of view and introduces, in marked contrast, the angelic revelation of the divine secret behind this humble appearance. The pronouncement of a saviour born "to you/us/ me" is the first and fundamental sermon in the new dispensation. Joy and praise remain its response. Luther's integral use of liturgical celebration is viewed in relation to the preaching by esp. Bernard of Clairvaux, whom he admired greatly. It is furthermore argued that his conscious affiliation to traditional elements of worship is not only a product of his confrontation with the "spiritualists", but can also be seen as an acknowledgement of the sermon's function in service and the need of talking and catechizing to the senses.
\end{abstract}

Key words: Reformation preaching - Christmas - liturgy - liturgical year - homiletics - medieval sermons - joyful exchange - Bernardine spirituality.

Den modne Luthers juleprædikener over Luk 2,1-14 har en påfaldende ens struktur. ${ }^{1}$ Luther opererer i overensstemmelse med tekstens forløb med to konsekutive og ret skarpt adskilte punkter, historia, som er evangelistens dystre beretning om en fødsels forløb under elendige forhold, og den ledsagende predicatio, som udlægger begivenhedens betydning, og som Lukas "overlader" til englen og det ledsagende englekor med deres helt anderledes stemmeføring og stemningsleje. Lys og munter tale bryder ind i den tavse mørke vinternat. Til disse

1. I det følgende henvises til Luthers værker med de almindelige forkortelser for hhv. Weimarer Ausgabe (WA), hvor ingen anden tekstmulighed foreligger, og Cl.A.,hvor den mere håndterbare "Clemen Ausgabe" kan konsulteres. Manuskriptbetegnelser forklares neden for i teksten. 
to punkter føjes principielt som et tredje "evangeliets frugt", som er tak og lovprisning, og hvor de næsten overstadige engles sang forenes med menighedens, således som det manifesteres i højmessens liturgiske led "Gloria in excelsis Deo". "Denne fødsel" er nemlig af en sådan art, at "den ikke fører andet end lovprisning med sig". I det liturgiske Gloria gentages englekorets respons på "den første prædiken i Det Nye Testamente", ${ }^{3}$ en lovsang, "som gav genlyd i himmel og på jord" (WA 29, $652[\mathrm{R}]$ ), "som vi har dagligt i messen" og "skal indøve godt i kristenheden". "Gudstjenestens taksigelse følges op af de troendes taknemmelighed, som den bør ytre sig i deres omgang med næsten, og hvor hyrdernes tilbagevenden til de dyr, som stadig skal røgtes, giver god anledning til at betone livet "i kald og stand". Julens cyklus følges over flere dages gudstjenester, og de bevarede prædikenoptegnelser vidner således om en forkyndelse, der var fast indlejret i både den gudstjenestelige højtid og den kirkelige kalender.

Luther var sig overordentlig bevidst, at den årlige julefest med dens rituelle og årstidsbestemte elementer hvilede på kirkelig tradition. Højtiderne havde været genstand for megen skepsis i reformationens start, og i 1524 afskaffede bibeltro reformatorer i Strassburg alle dem, der ikke faldt på en søndag, herunder julen. Det blev imidlertid hurtigt mærkbart, at denne i sig selv legitime reformatoriske fornyelse afstedkom et "hul" i det frelseshistoriske narrativ", og erfaringer som denne reflekteres givetvis i de kateketisk vinklede overvejelser over kirkeåret, som findes $\mathrm{i}$ Luthers prædikener til de store festdage $\mathrm{i}$ årene efter. ${ }^{7}$ Selve betegnelsen "kirkeår" er efterreformatorisk og er næppe

2. WA 17,I, $499[\mathrm{H}]$ : "hoec nativitas nichil aliud secum fert nisi lauden".

Om den nære sammenhæng mellem luthersk teologi og den musikalsk udmøntede praxis pietatis i den lutherske verden med netop lovprisningen som omdrejningspunkt, se: Sven Rune Havsteen, "Aspects of Musical Thought in Seventeent-Century Lutheran Theological Tradition", The Arts and the Cultural Heritage of Martin Luther, Special Issue of Tranfiguration. Nordic Journal for Christianity and the Arts 2002, (København: Museum Tusculanum 2002) 151-169.

3. WA 29, 656 [R]: “...prima et optima praedicatio, quia prima quae facta in novo Testamento. Ex qua sind die, die allen andern gesponnen in toto novo Testamento". 4. WA 10,1,88: "den Englichen gesang..., den wyr ynn der Mess teglich habenn: Gloria..."; WA 17,I, 499 [H];WA 27,503 [R]: "pulcherrimum canticum, den man wol in der Christenheit uben sol 'Gloria'”.

5. WA 27, 509-518: Prædiken til 2. Juledag, som rummer en hel lille etik.

6. Katharina Schütz Zell, Writings II, ed Elsie Anne McKee, Leiden: Brill, 1999, 61. 7. F.eks. WA 32, 251 [R]: "Es ist ein fein loblich gewonheit, das man die Euangelia stuecke hat auff die Sontag non solum...sed ideo potissimum, das der junge hauffe, der her wechsscht, et der einfeltig man, qui se per annum non viel bekomert, ut habeat ein tag ym jar, ut audiat historiam Nativitatis, passionis et resurrectionis, ut sciat, wenn er anderswo sc." Ibd. [N]: "Es ist eyne feyne lipliche gewonheyt, ut euangelia aliqua partita sint ad certa festa, ut repetantur..." 
tilfældigt dannet i en postil på luthersk grund. ${ }^{8}$ Fastholdelsen af det kulturelt fasttømrede univers, den kirkelige kalender udgjorde, skulle give kirkegængerne lejlighed til at dvæle ved de kendte fortællinger og lade budskabet nedfælde sig, før de vendte tilbage til deres dagligdag.

I det følgende skal en række af Luthers juleprædikener betragtes nærmere. Tyngdepunktet er lagt i 1525-1530, hvor Luther fremstår som en moden prædikant, der har fundet sin egen form. Opgøret med spiritualisterne har uden tvivl bidraget til den genopdagelse og værdsættelse af det traderede religiøse formsprog, som optegnelserne vidner om, mens den fornyede styrkeprøve med Romerkirken op til 1530 på den anden side har reaktualiseret hans kritik af katolsk ceremoniforståelse. Men primært har han kunnet øse af en gennem årtier opbygget indsigt i forkyndelsens vilkår i den såkaldt almindelige befolkning.

Følgelig skal Luthers juleprædikener først anbringes i den homiletiske tradition, som han bevidst tog op og førte videre på sine egne præmisser.

Prædikenerne fremstår i Weimarudgaven som den "notetagning", de er, med stikord og halve sætninger på latin og tysk mellem hinanden. Mest omfattende er noterne fra Rörer (R), der ifølge almindelig konsensus er den, der kommer nærmest på at gengive Luthers prædikener, som de blev holdt. Et par anonyme optegnelser, Nürnbergms. $(\mathrm{N})$ og Hamborgms. (H) bærer samme autentiske præg. Den sprogligt vanskelige form udgør desværre en barriere for læsningen af disse prædikener, som derfor ikke har fået den opmærksomhed, de fortjener. ${ }^{9}$ Der citeres og/eller oversættes derfor i det følgende udførligt fra teksten.

\section{Forbindelsen bagud: Glæden og dens manifestationer}

Med udnyttelsen af de elementer, traditionen bød ham, indskrev Luther sig i en middelalderlig tradition for at lade den liturgiske fejring af julen præge formidlingen af dens budskab.

Både hos Bernhard af Clairvaux (12. årh.) og i den tyske mystik hos eksempelvis Johannes Tauler (14. årh.) finder vi således juleprædikener, der forudsætter de troendes medleven i og tydning af det

8. Frieder Schulz, Synaxis, (Göttingen: Vandenhoeck \& Ruprecht 1997), 361.

9. Dommen over alt andet end disse optegnelser har ellers været hård i den del af Lutherforskningen, der har ønsket at betone Luthers prædikenform som et mundtligt kerygma uden de svinkeærinder, der tillægges postillerne. Cl.A.7, VII; Erwing Mühlhaupt, "Luther der Prediger". Wege zum Wort (Berlin 1967). 
gudstjenestelige ritual. Luther kendte og højagtede begge for de produkter, der forelå fra netop deres forkyndende virksomhed.

Bernhards prædikener forelå på tryk i Augustinereremitternes bibliotek i Erfurt. ${ }^{10}$ Luthers studium af dem fremgår af en række citater, men også af direkte udtalelser, hvori han ytrer sig om dem i superlativ, mens han samtidig diskvalificerer Bernhards systematiskteologiske arbejde:

Bernhard overstråler i sine prædikener alle andre doctores, selv Augustin. For han lærer Kristus på en meget fin måde. Men i sine disputationer er han en helt anden og ganske modbydelig... ${ }^{11}$

Det turde være overflødigt at bemærke, at Luthers "hvide snit" ikke er en farbar metode for den, der vil sammenligne de to mænds prædikener med henblik på deres teologi. I en stor undersøgelse af teologien i Luthers prædikener gør Ulrich Asendorf således den iagttagelse, at Luther særlig i sin forkyndelse af juleevangeliet gerne refererer til liturgiske tekster. ${ }^{12}$ Som følge af sin snævre fokus på forkyndelsens teologiske indhold tematiserer han imidlertid ikke forholdet mellem gudstjeneste og prædiken. De liturgiske henvisninger anskues omtrent som de ofte berømmede islæt af "folkelighed" blot som noget, der skal gøre talen mere levende - og som desuden kan retfærdiggøres med deres bibelske oprindelse. Spørgsmålet er imidlertid, om en sådan læsning reelt fanger datidens forkyndelse af julebudskabet.

I sin undersøgelse af ritualet som en særlig erfaringsdimension har Bent Flemming Nielsen gjort opmærksom på, at den gudstjenestelige prædiken er en kommunikation, der finder sted inden for en fast og kendt liturgisk ramme. Denne ramme forlener den med en egenart, som ikke dækkes af de eksisterende kommunikationsteoretiske eller teologiske definitioner på, hvad en "prædiken" er. ${ }^{13}$ Denne opfattelse bør efter min mening i høj grad tages ad notam, hvis man ikke vil blive stånde ved et signalement af prædikenernes teologiske indhold på den ene side og en karakteristik af deres virkemidler på den anden.

Den liturgiske ramme om julefesten, som Bernhard bevæger sig inden for, fremgår klart af en række prædikener til julenat, som kredser

10. Franz Posset "Bernhard von Clairvauxs Sermone zur Weihnachts-, Fasten- und Osterzeit als Quelle Martin Luthers", LJB 61(1994) 95.

11. WA T 1, Nr. 871: "Bernhardus ubertrifft in seinen Predigten alle andere Doctores, auch Augustinum selber, denn er lehret Christum sehr fein; aber in seinen Disputationibus ist er ihm selbst gar ungleich und gar widerwärtig...

12. Ulrich Asendorf, Die Theologie Martin Luthers nach seinen Predigten, (Göttingen: Vandenhoeck \& Ruprecht 1988) 84.

13. Bent Flemming Nielsen, Genopforelser. Ritual, kommunikation og kirke, (København: ANIS 2004) 100-103; 145-167. 
om den cisterciensiske tekstlæsning "Jesus Christus, flitus Dei, nascitur in Bethlehem Iudae" (Jesus Kristus, Guds søn, fødes i Betlehem i Judæa). ${ }^{14}$

Som åbning på første prædiken lader prædikanten sig overvælde af den resonans, "glædens stemme, jublens og frelsens stemme" har efterladt sig. Jesus fødes! Lad enhver fryde sig, som er belastet af bevidstheden om sine synder (BSW VII, 134)! En særlig vægt ligger på verbets præsensform, som gøres til eksplicit genstand for argumentationen i sjette prædiken til julevigilien. Her rejses nemlig det spørgsmål, hvordan man kan forstå en gammel, velkendt meddelelse som en forkyndelse til nutiden, således som teksten grammatisk lægger op til. Diskussionen fremlægges som en aldeles lunken munks vrangvillige spørgsmål til kirkens fremsyngelse af nascitur. Denne fødsel er dog en gammel sag! Hvad har den med "i dag" at gøre? Svaret ligger i forståelsen af, hvordan et ritual fungerer. Bernhard peger på de rituelle handlinger, som hans tilhørere netop har udført som respons på teksten: "Da bebudelsens stemme lød i jeres ører, brød I ud i glædesjubel, I takkede og tilbad, mens I lå udstrakt på jorden..." (BSW VII, 238). ${ }^{15}$

Kun fordi ritualet korresponderer med troens indre bevægelse er det relevant at referere til det. Glædens manifestationer afspejler, siger Bernhard, en reception af budskabet, der altid opfatter det som "nyt", fordi det fornyer sjælen og forvandler det gamle liv til et nyt. Det kan ikke andet, fordi alt, hvad der er gammelt, er uforeneligt med dette budskab. Derfor står "Kristus, Guds søn, fødes" altså i grammatisk nutid, selv om der tales om én, der er født forud for al tid, og som kom til de gamle som den forjættede, før end han blev klædt i kød. Engang i fortiden begyndte dette ord at høres og, som Bernhard tilføjer, ingen af de hellige har indtil nu fàet nok af det. Julebudskabets proklamation af Jesu fødsel sammenlignes med nadvermysteriets forkyndelse af Jesu død. Han fødes virkeligt og aktuelt, og der skabes frelse, hver gang inkarnationen fejres.

\section{Jesusbarnet og Kristi menneskelighed}

Luthers betagelse af Bernhards prædikener skyldtes i høj grad den sans for Kristi fulde menneskelighed, som var Bernhards særlige varemærke (Posset (1994:97) - og som rent historisk har bidraget ikke

14. Bernhard von Clairvaux, Sämtliche Werke lateinisch/deutsch Bd. VII, hrsg. Gerhard B. Winkler, (Innsbruck: Tyrolia-Verlag 1996) 130 (I det følgende BSW VII). 15. "...ubi facta est vox annuntiationis huius in auribus vestris, exultastis in gaudio, egistis in gratias, prostrati solo tenus adorastis..." 
så lidt til den vesterlandske kirkes fokus på "det spæde barn i krybben”. Luther læste vedblivende hans prædikener, og så sent som 1539 udtalte han, at

Is sic diligit Christum und redet und prediget susse von im, das ein lust ist, quando quis legit. (WA 47,694) (Han elsker Kristus i den grad og taler og prædiker så sødt om ham, at det er en lyst, hver gang man læser det).

Bevidstheden om, at ordet ikke blot blev menneske, men blev det $\mathrm{i}$ form af et spædbarn fremmes hos Bernhard i tilspidsede formuleringer, hvori han leger med den sacrosancte formel fra den nikænskkonstantinopolitanske trosbekendelse, som blev fremsunget i messen: Verbum homo factus" kan således blive til "Verbum infans" ("Ordet blev barn”) eller: "...Deum parvulum factum” (“...Gud blev et spædbarn”) (BSW VII, 266). Bernhard tolker Kristi menneskelighed som en imødekommelse af menneskets behov for en frelser, der var "ham lig i alle ting undtagen synd" (Hebr 2,17-18; 4,15-16), og med den nyfødtes på alle måder usle og hjælpeløse fremtoning vil han betone den kristne bekendelses unikke karakter:

Vi ærer ham i krybben...Vi tager imod ham, som blev svag for vor skyld (propter nos), korsfæstet for vor skyld, dødsbleg for vor skyld, ... (BSW VII, 271)

lyder en original gengivelse af Trosbekendelsen.

Beretningen om den historiske Jesus' liv helt ned i detaljen og den kristnes tilegnelse af alt dette som "mit" sætter den faste ramme for Luthers juleprædikener, hvor de så at sige fusionerer med hans kateketiske forklaringer til anden trosartikel. ${ }^{16}$

I Bernhards eftertid nød navnlig den såkaldt tredje prædiken over fødsel og lidelse udbredt opmærksomhed. Bernhard indleder med at opsummere julefestens mirakuløse begivenheder, både de skjulte og de åbenbare, til og med hyrdernes spredning af budskabet. Alle disse ting er af guddommelig art, og rækkes os på denne særlige dag i kar af guld. Men det er indholdet, der vil betragtes, den guddommelige visdom, som er en forkastelse af alt det, verden ville vælge, og følgelig

16. Slægtskabet mellem Bernhard og Luther blev først rigtigt erkendt af Lutherforskningen i 1990'erne, ikke mindst i kraft af Theo Bells store dokumentationsarbejde Divus Bernhardus: Bernhard von Clairvaux in Martin Luthers Schriften, (Mainz: P. von Zabern 1993). Det synes imidlertid at have været umiddelbart klart. for samtiden, således som det fremgår af Poul Helgesens indledning til hans danske oversættelse af Betbüchlein 1524. Ninna Jørgensen, "Megh til gode" i: Kirkehistorier-Festskrift til M.S. Lausten, København: ANIS 2008) 111-118. 
en prædiken til ydmyghed og omvendelse fra et klynkende spædbarn. Alt omkring ham, stalden, krybben, råber dette budskab ud. Betragteren erkender da, at Jesu fødsel med dens tid og sted, nattekulden, babykroppens svaghed, den lilles gråd, (men også hyrdernes fattigdom og nattevågen) "rækkes til mig", "sker for min skyld" og "til mit eksempel”. Barnets tårer, som foregriber det udgydte blod, vækker skammen og angeren hos den indtil da ubekymrede synder. Som i en vision ser han kongesønnen lægge sit diadem bort og begive sig ind under den dom, der var fældet over mennesker (BSW VII, 250-262).

Luther gengav Bernhards "vision" i en sermon om den rette måde at betragte Kristi lidelse på, 1519. Den selv- og syndserkendelse, betragtningen vækker, forandrer og genføder mennesket næsten lige som dåben: “...disses bedencken wandelt den menschenn wessentlich...", hedder det med en vending, der minder om hans samtidige juleprædikener. ${ }^{17}$

\section{Tauler og den unge Luther}

Johannes Taulers store prædiken "Om de tre fødsler" tager lige som Bernhards juleprædikener direkte afsæt i den liturgiske udformning af julenats/-dags messer. ${ }^{18} \mathrm{Om}$ natten afholdes en messe for den indretrinitariske fødsel $(S 12,7)$, der finder sted i mørket og er skjult for mennesker. Inkarnationen markeres med en messe ved daggry, som kredser om lysets komme. Endelig og i fuldt dagslys fejres den historiske begivenheds internalisering i menneskers hjerter - i Taulers karakteristiske sprogbrug: "Guds fødsel i os". Denne messes liturgiske udgangspunkt er Es 9,6 (filius datus est nobis).

Om de tre "fødsler" hedder det samlet i prædikenen, at de må fremkalde en så stor fryd i enhver kristen,

dass er usser ime selber springen in iubilo und in minnen, in dangnemekeit und inrelicher froeude (at han bliver ude af sig selv og springer i jubel og kærlighedslængsel, i taknemmelighed og indre glæde).

Der tilføjes et dystert memento til dem, der ikke vækkes til glæde af dette budskab:

weler mensche des nit in ime bevint, der mag sich voerhten. (det menneske, der ikke erfarer dette i sig selv, han må frygte!)

17. Cl.A. I, 158.

18. Ferdinand Vetter, Die Predigten Taulers, (Berlin: Weidmansche Buchhandlung 1910) 7-12. 
Blikket på "outsideren” og hans manglende festglæde (jævnfør gæsten uden festtøj Matt 21,11-14) går igen hos alle tre teologer.

Luther kommenterede Taulers prædikener, mens han stadig forelæste over Romerbrevet i 1516 og udgav og genudgav dem selv. ${ }^{19}$ Hans veneration for mystikeren skal have holdt sig livet igennem ${ }^{20}$, selv om han efter konfrontationen med "sværmerne" blev markant tilbageholdende med at bruge hans særlige vokabular. ${ }^{21}$ Netop den pågældende juleprædiken var genstand for indgående kommentarer (de såkaldte "randbemærkninger"), og Luther førte tilmed talen om "Guds fødsel i os" videre i kommentarerne til en anden af Taulers prædikener. Man skal imidlertid være varsom med at udlede for meget af denne "genre", da den ikke umiddelbart og entydigt røber, hvordan forfatteren har læst teksten. I denne artikel, hvor det ikke drejer sig om hverken at be- eller afvise Luthers "mystiske" rødder, skal blot konstateres, at Tauler lige som Bernhard befinder sig i den af Luther kendte homiletiske tradition for at fremhæve julens til overstadighed grænsende glæde og se den traderede liturgiske form som passende ramme om dens budskab.

Hjertets affekt optræder som en naturlig ledsageomstændighed til tilegnelsen af budskabet i to prædikenfragmenter fra 1520. De viser den unge Luthers endnu eksperimenterende omgang med Jesu fødsel, som, siger han, kan tilegnes på to måder (WA 9, 517-520). Den første er, "når betragtningen ikke rører hjertet, når det hverken forandres eller føler nogen sødme, ikke indser, hvilken trøst for menneskenes sjæle, der er nedlagt i denne betragtning: Hjertet ler ikke og er heller ikke glad".

Primo si precordia non tangat meditatio, neque immutantur neque dulcedinem aliquam sentiunt, non certe intelligentes, quantum humanis animis solatio situm sit in hac meditatione. Daß hercz lacht nicht, ist auch nicht frolich.

Dette tilfælde er beskrevet hos profeten, som siger, at Samaria lod sin konge rejse igennem sig som "skum på vandets overflade" (Hos 10,7). Skum forbliver på overfladen og når ikke i dybden, til hjertet. Samtidig er der en sådan overflod af guddommelig godhed i denne fødsel, at vi ville "opløses i en alt for stor glæde", hvis vi så eller forstod

19. Cl. A. V, 305-310.

20. Bernd Moeller, "Tauler und Luther". La mystique Rhénane, (Paris: 1963), 157168.

21. WA Br III, 120;763. Jf. Ninna Jørgensen, "Hat Luther Müntzers Liturgiereform abgelehnt?" ARG 80 (1989) 64-65. 
den til bunds. ${ }^{22}$ Den anden mulighed er, at hjertet bliver stort og fedt af den nærende spise, der findes i betragtningen af julebudskabet, en kulinarisk talemåde om åndelig næring, som i parentes bemærket er karakteristisk bernhardinsk.

Luthers tale om to slags mennesker eller to betragtningsmåder ud fra profetens udsagn om skummet og det dybe vand findes i en samtidig og beslægtet prædikenoptegnelse, hvor det hedder, at Jesus endnu ikke "er født for Samarias befolkning", hvorimod "vi" (:de få) bevæges og "entpfinden ein wandel in unsern hertzen noch dieser bedenckung..." (føler en forandring i vort hjerte ved denne betragtning) (WA 7,188). Juleevangeliet forandrer "hjertet" hos de troende. Denne opfattelse kommer med tiden til forskelligt udtryk hos Luther. I 1520 var det ham magtpåliggende at eksplicitere, at de affekter, han talte om, ikke havde rod i noget hos det gamle menneske. Troens glæde var en del af den ny skabning, der først kan "fødes" i mennesket, når det er tomt, vacuus, dødt og borte for det skabte, (gelassen). Den kunne ikke beskrives, men måtte erfares af den enkelte. Efter 1523 (hvor selveste Karlstadt udgav en massiv traktat om Gelassenheit) ${ }^{23}$, forsvandt den umiskendeligt taulerske sprogbrug og antropologi fra Luthers prædikener. Man kan diskutere, om det kun var sproget, der ændredes, men det er ikke stedet her. Den modne Luther priste fremover stadig den overvældende glæde, der ledsagede julebudskabets proklamation, men han udtrykte sig langt enklere om så vel den positive som den negative respons på det. Han var overbevist om, at den, der ikke følte glæde ved denne prædiken, ikke havde grebet, at dette var noget, der var sket pro me. I 1530 finder vi følgende opsummering af ti års prædikener over juleevangeliet:

Se, om du er kristen. Hvis du kan synge: Den søn, der prædikes, som er Herre og frelser, han er min frelser; og kan du... af hjertet sige ja til (englens ord) og tror det, da bliver hjertet fuldt af tillid, glæde...Du ser, hvordan et menneske jubler, når det får en kappe, hvor meget mere skal da ikke de juble, springe højt, som hører englens"Jer"? ... det kan ikke fejle, hvis hjertet tror, så må det elske moderen Maria, drengen og især Gud Fader. For hvis det er sandt, at han (Kristus) er født af en jomfru og er min, så har jeg ikke en vred Gud. Jeg må erkende, at der er idel latter og glæde i Faderens hjerte...større ord kan jeg ikke tale...Jeg vil helst høre det talt og sunget: Så længe der ikke

22. WA 9, 517: “...tanta exuberantia divinae bonitatis est in hac nativitate, ut si videremus aut penitus cognosceremus, continuo prae nimio gaudio dissolveremur." 23. Andreas Bodenstein von Karlstadt, Was gesagt ist: Sich gelassen, und was das Wort Gelassenheit bedeutet, und wo es in heiliger Schrift begriffen. Engelsk E.J. Furcha, The Essential Karlstadt, (Ontario: Herald Press, 1995), 133-168. 
er glæde, er der kun lille eller ingen tro, og da tror du ikke englen" (WA 32, 267-268).

\section{Luthers juleprædikener 1525-1530}

Den todelte struktur i Luthers juleprædikener bliver for alvor synlig fra og med 1524, for lige som at falde på plads og tilmed reflekteres i de følgende sæsoner. Den faste form udelukker ikke, men skaber tværtimod plads til skiftende pointeringer med polemik mod både middelalderkatolsk prædiken og spiritualistiske positioner, samt kateketiske tiltag.

I de to overleverede nedskrifter af Luthers juleprædiken fra 1525 introduceres tekstens to dele og kontrasten mellem dem uden præambel med korte rammende karakteristikker. (WA 17, I 496b-500b). Der er 'historien', og den går kort fortalt ud på, at det hele for en ydre betragtning er en jammerlig affære: "1. historia. Historia est, quod sit ein jemerlich ansehen"! hedder det summarisk i Rörers nedskrift En ringe og ukendt person fødes midt $\mathrm{i}$ den kolde sorte vinternat på et fremmed sted, hvor alt mangler, en tiggers fødsel. Det totale fravær af alt, hvad der tager sig ud i verdens øjne, udnyttes straks moralsk til at kundgøre, at vi er blinde for den sande skat, vi befinder os i mørket og hylder falske værdier. Til den almene visdomsbelæring knyttes yderligere den reformatoriske erfaring, at ordet vises en lignende ringeagt, når det forkyndes uden filosofi og falbelader. Det henvises til samme skyggeeksistens som det fattige barn, ingen vil kendes ved.

Udlægningen af "det andet stykke", englens prædiken, koncentrerer sig om ordene "Frygt ikke!" Frygten er et eksistensvilkår i denne verden, dels fordi der er synd, og dermed dårlig samvittighed, dels, ganske enkelt, fordi vi bekymrer os i almindelighed. Englens ord viser en udvej ud af denne fastlåsthed i frygt. Denne udvej fremgår nøje af hans formulering med sammenstillingen af elementerne "en frelser" og "født JER". Med en traditionel læsning af S1 51,7 om arvesynden kontrasteres vores undfangelse og fødsel i synd og urenhed med Kristi undfangelse ved Helligånden og fødsel af Maria. I kraft af det "kød og blod", drengen har fået fra Maria, har han samme natur som os, men ren og ubesmittet. Denne nye fødsel rækker Kristus os, og idet han således deler fødsel med os, kan vi betragte os som "Marias børn” med lige så stor ret, som han selv gør det.

Således blandes begge fødsler for at blive til én. Således bliver også jeg og enhver, der tror, Marias søn og kan nu prale af ikke at være en synder("seque nunc iactat non peccatorem"), men genfødt i Helligånden (WA 17,I,498a [H]). 
Dette er noget andet end at være den kvindes barn, som med salmistens ord tvinges til at sige "Se, i synd har min moder undfanget mig etc. ..."!

Det troens 'praleri', som her omtales, er den rette fejring af julens fest og sætter én i stand til af hjertet synge 'ein kindelein so lobelich' ('Et lidet barn så lysteligt') (WA 17, I, 499a [H]).

Luther refererer hermed til andet vers i en populær menighedssalme fra det 14. århundrede, som meget tidligt blev annekteret af reformatorerne. Malling anfører, at Luther i en juleprædiken 1545 specifikt knytter denne salme sammen med Es 9,6; ${ }^{24}$ men allerede i juleprædikenen af 1520 omtaler han den som en udtømmende tydning af Esajasforjættelsens "nobis"

Hoc testatum est prophetarum oraculis, Esa. 9. 'Parvulus natus est nobis, et filius datus est nobis'. Ehr ist unßer, der son...Spiritu docti sunt qui hanc cantionem non minus iucundam quam spiritalem effinxerunt: Eyn kyndeleyn ßo lobelich ist unß \&c.. In qua cantione nihil obmissum est, quod posset ad spiritalem huius nativitatis intelligentiam pertinere. (WA 9,518). (Dette er bevidnet af profetierne Es 9 "et barn er født os, en søn er os givet". Han er vor, sønnen. Oplærte af Gud er de, der har forfattet denne sang, som er lige så liflig som åndelig: Et lidet barn så lysteligt etc. I denne sang er intet udeladt, som kunne henhøre under den åndelige forståelse af denne fødsel)

De kristne, der nu har set Guds herlighed (Gloria), frygter og bekymrer sig ikke længere. Med denne lovsangs anden strofe 'Fred på jorden' vises tilbage til englens indledende trøstende 'Frygt ikke!' Den glæde, der ledsager julens budskab, driver al frygt bort.

I 1528 - året for intenst katekismearbejde - fremhæves først den egenskab ved teksten, at den fremlægger det historiske grundlag for Trosbekendelsens "født af jomfru Maria". Som tekstbasis for den lære, menigheden kender fra trosartiklerne, fremstår evangeliet med beretning og forkyndelse som en helhed, hvor "både jord og himmel" bevidner, at Jesus er Guds søn og Marias barn.

Derefter rekurrerer Luther ikke desto mindre til tekstens to niveauer. Om historia hedder det først, at det er "ret og billigt" at opholde sig ved den for menigmands skyld, propter simplices. Først efter at have vist menigheden rundt $\mathrm{i}$ det historiske sceneri, vil han vende sig til englens budskab. Genfortællingen går i detaljer, til og med det "varme vand", der mangler til barnets bad, og som Luther - i betragtning af de øvrige mangler - "slet ikke vil tale om"! De barske vilkår

24. Anders Malling, Dansk Salmehistorie, bd. I, (København: J.H.Schulz Forlag, 1962) 364-66. 
tjener til at demonstrere, hvad det er for en Gud, der er kommet til os, og "pirrer" eller "varmer" hjertet, så det elsker den lille dreng. De kristne skal indpræge sig billedet af barnet ved æslet og bruge det som eksempel på ydmyghed. Dette er, hvad Kristus har villet vise os med den fornedrelse, der knytter sig til hans livs begyndelse, og som altså har en tilsigtet pædagogisk betydning. Henvisningen til Kristi eksemplariske ydmyghed, som bibeholdes årene igennem, var også markant fremme i Bernhards juleprædiken og må vel siges at have status af et topos.

Den affektive tilegnelse af fortællingen er vigtig, men det er til syvende og sidst det personlige pronomen i englens budskab, der er afgørende for, om der kan tales om kristen tro. Med en henvisning til datidens almindeligt kendte skolastiske distinktioner mellem "tro" (at Gud er til) og "tro" (hænge ved ham i kærlighed) ${ }^{25}$ hedder det, at alle kan "tro", at Jesus er født, fra Satan selv over papister til sværmere; de godtager tildragelsen som historisk faktum; men det er næsten umuligt at fatte, at det er sket for min skyld, at barnet er mit lige så vel som Marias. Hvor noget sådant alligevel måtte ske, og det sker kun ved Guds indgriben, "der følger glæden. Hvis glæden ikke følger, er det et tegn på, at du ganske vist tror, han er født, men ikke for dig” (WA27, 493b).

Den fremskudte position, det personlige pronomen "jer" har i frelsesbudskabet, viser også, hvem "vi" er - som i modsætning til englene har frelse behov. På englens opfordring vendes vores blik bort fra os selv til den Gud, der har villet lade sin søn føde tibi, for dig. Englens "VOBIS" bør skrives med store bogstaver", for det er svært at fatte, at der gives en sådan skat. "Derfor bør vi især øve troen i sådanne og lignende ord Euch, dyr, myr" (WA 27, 493b [N])

Forholdet mellem englene og den faldne menneskehed er et tilbagevendende tema i prædikenerne. Det ligger bag den genoptagne tanke om "troens praleri", som hævder, at barnet er "mit" så vel som Marias. Den, der ikke vil tage imod Guds frelse, som den tilbydes i englens "JER er en FRELSER født", gør Gud til en løgner. Troens "praleri", som "Maria ikke vil anse for "hovmod" modstilles altså den djævelske ursynd, som vil frelse sig selv.

Mens budskabets indhold og dets personlige adresse står i forgrunden i morgengudstjenesten, fremhæves dets ydre aspekt i eftermiddagens gudstjeneste, hvori Luther vender sin opmærksomhed mod hyrderne.

Disse hyrder havde kun englens mundtligt formidlede ord at holde sig til. Uden dette ord havde fødslen imidlertid været til ingen nytte,

25. Jf. Petrus Lombardus, Sententiarum libri IV, Ad Claras Aquas 1916, tom II, Dist. XXIII, cp. iv, 636. 
for hvem kunne så vide, hvad det var for en særlig fødsel? Denne fokus på "det ydre ord" udnyttes til det yderste mod spiritualisterne. Luther drager næsten pedantisk fordel af den omstændighed ved evangelietekstens opbygning, at så vel de formentlig "fromme onkler og tanter" i Betlehem som det rå klientel, der arbejdede i samfundets udkant, befandt sig i total uvidenhed om Guds søns fødsel, indtil englen trådte frem og lod sin stemme høre. Der findes ingen anden vej til kundskab om Gud end "det ydre ords forkyndelse", som englen startede, og som hyrderne troede, mens resten af verden lå hen i mørke.

Det beror muligvis på denne ekstra gevinst ved Lukas' tilrettelæggelse af sin beretning, at Luther i de kommende sæsoner yderligere perfektionerer sin adskillelse af begivenheden, som den tager sig ud i jordisk perspektiv, og proklamationen af dens betydning fra himlen.

I 1529 går han ligefrem bag om evangelieteksten og fremstiller dens dobbelte fremtoning som en redaktionsproces fra Lukas' side: Evangelisten har med flid nedskrevet historien og derefter inddelt den i to stykker. Først beskriver han "de elendige, jammerlige hændelser på jorden“, dernæst den glæde, som disse hændelser må fremkalde, når menneskene får dem meddelt. Afstanden mellem de to former for "virkelighed" træder dramatisk frem i det sammenstød mellem modsætninger, englenes tilsynekomst afstedkommer. Den dystre historie med dens uundgåeligt endnu tristere afslutning: "ingen agter på det, ingen ved det", forvandles med englens prædiken. Klarhed, lys, lyd træder i stedet for det ubekendte mørke:

Han får mørket til at forsvinde og åbenbarer den gerning (der er sket), dvs. han tilføjer prædikenen...Derefter synger englene, så himlen og jorden giver genlyd (WA 29, 651-652 [R]).

1530 reflekterer han på ny over evangelistens strukturering af teksten, nu som udgangspunkt for en redegørelse for tonaturlæren. Lukas har "for sin egen del skrevet skrevet historien enkelt, lige som en hvilken som helst anden historie" (WA 32, $256[\mathrm{R}]$ ). ${ }^{26}$ Han holder sig til, hvad en samtidig iagttager ville have set og hørt. I $\mathrm{N}$ hedder det tilsvarende, at Lukas skriver yderst ligefremt som om en almindelig fødsel uden smykkende ord ("simplicissime wie sunst von eyner gemeynen gepurt. Non illum rethoricis laudibus evenit"). Den retoriske lovprisning overlader han til englene: "Das lest der Lucas an sthen et tribuit angelis, die eine heller stymm". Lukas agerer den historiker, han var, og lader himmelske væsener forkynde, hvad der er at vide derudover.

26. “...pro sua persona descripsit historiam simpliciter, quasi de alia historia”. 
Englene kommer ind i stalden og til svøbene og herliggør Gud med deres sang, således at begivenheden ikke forbliver skjult. De kender barnets navn og titler. De ved, at et menneskebarn er deres Herre. Havde de været som mennesker, havde de "skulet" (egl."lavet skeløjne”) og ikke undt os den ære, at vort kød og blod er deres Herre. Men de fryder sig, "... de er af hjertet glade, ler, fylder hele himlen og jorden med deres sang (om), at vi har en frelser, som er deres Herre". (WA 32, 257a [R]) Når disse højere væsner, som kun kan anerkende Gud som deres Herre, giver et menneskebarn denne titel - og med glæde - "beviser" dette den kristne tros sværeste påstand, at Kristus er sandt menneske og sand Gud. Dogmet udledes af det ydre ords nøjagtige form og fastholdes i tiltro til det mod alle fornuftens indvendinger.

Englenes rolle som de første der åbenbarer en skjult guddommelig virkelighed er et markant indslag i Luthers forsøg på at forklare hvordan evangeliet (og de deraf følgende dogmer) bliver kendt, ikke blot julenat, men også påskemorgen. Begge steder lyder deres "Frygt ikke!" og begge steder er deres væsen lutter venlighed og en glæde, der grænser til det pjattede:

Se derfor, hvordan de kære engle i fortællingen taler så venligt med Maria Magdalene og de andre kvinder, som drev de deres spøg med Magdalena: Det ser næsten ud som gjorde de sig i deres vished og glæde lystige over hendes gråd og sagde: Du er en værre tåbe, at du græder i den store, høje glæde! ${ }^{27}$

Kædet sammen med englenes venlige fremtræden er det gudsbillede, de bringer med sig, da de fører hyrderne med ind i stalden

Vist frygter vi ikke en ung pige på 15 år. Og slet ikke når hun lige har født og ikke kan finde ud af andet end at amme barnet. Det er jo et venligt billede! Vær vis på, at du ikke véd af nogen Gud uden om dette billede, men at dette er frelseren og Herren, som har magt over død og synd. Det (:barnet) kan knap nok bevæge sig og rette de små fingre ud...Og derfor, fordi det er så absurd og skjult, bør englen komme og prædike, så at man fatter det med ordet, hvis man ikke kan fatte det på anden måde (WA 29,226 [R]).

Med etableringen af dette gudsbillede bruger englene "deres kunst" for at glæde os, lige som Lukas har brugt sin (ibd.).

27. Gengivet efter Georg Heckel, "Martin Luthers Osterpredigt", Luther als Prediger. Veröffentlichungen der Luther-Akademie Ratzeburg 9, (Erlangen: MartinLuther-Verlag 1986) 21. 
Den stærke vægtlægning på det ydre ord og dets fremtræden for alle sanser vil næppe forlede nogen til at tro, at Luther så formen som en nødvendig ingrediens i budskabets formidling. Den unge Luthers holdning til det katolske ritualvæsen var næsten "puritansk", farvet som den var af renæssancehumanismens ceremonikritik og den tyske mystiks inderliggørelse af det religiøse liv i "forskelsløshed" i forhold til tid, sted og handling. Denne holdning fastholdt han og betonede heroverfor den troendes tilegnelse af det personlige pronomen som "det ene nødvendige". I 1530 fulminerer han således over "d' herrer" papister, især i klostrene, der holder trefoldige messer og synger englens ord med orgel til, men i hjertet ærer en anden frelser end ham, der "ligger i krybben" og "på sin moders skød". Ceremonikritikken gælder den gerningsretfærdighed, der var knyttet til en foreskreven udførelse af gudstjenestelige handlinger. Kritikken forbindes derimod ikke med formidlingen af ordet $\mathrm{i}$ en sanselig form, der vækker glæde, og som værdsættes som den "kunst", den er.

I Rörers manuskript til denne stærkt antipapistiske prædiken er bekendelsen til barnet i krybben og på moderens skød som eneste frelser forsynet med en rettelse. "I krybben" (in presepio) og "i (moderens) skød"(in gremio) indgår i den middelalderlige sekvens"In dulci iubilo" fra det 14. århundredes Tyskland, ${ }^{28}$ og skriveren har simpelthen taget disse ord som stikord og sat hele salmen ind - og minder os således, sig selv uafvidende, om den kirkelige traditions information af juleprædikenen, netop hvor denne prædiken er mest kritisk over for katolsk ritualfromhed:

in gremio durchgestr... Dafür

In dulci iubilo, nu singet und seid fro,

unsers hertzen wonne leit in presepio

und leuchtet als die Sonne

matris in gremio, alpha est et o. (WA 32. 270: noter til R)

\section{En note om Maria}

Den fremtrædende rolle, Maria får tildelt i juleprædikenernes udfoldelse af "det salige bytte", giver anledning til at standse op et øjeblik og betragte Luthers opfattelse af Jesu moder.

Luther fastholdt, at Maria "teknisk" set var jomfru, men at det ikke var dette mirakel, der skulle betragtes, men derimod den guddommelige handling, hvorved Gud nedlod sig i hendes skød, således at

28. Salmen nævnes i en vision af ubeskrivelig glæde og dans med høje spring hos den tyske mystiker Suso ( Malling: 1962, 340). 
"naturerne" kunne forenes. Netop med "det salige bytte" in mente ville det have været meningsløst at hæve hende ud over de vilkår, der klæbede ved menneskeheden.

I juleprædikenerne af 1520 og igen i sin store udlægning af Marias lovsang, "Magnificat", 1520-21 ${ }^{29}$ fortolkede Luther profetien Es 11,1 "...der skyder en kvist af Isajs stub, et skud gror frem af hans rod" ud fra en korrekt opfattelse af leddenes parallelisme. I den traditionelle katolske udlægning af profetien indeholder teksten to forjættelser. Kvisten (latin: virga) forbindes med virgo, jomfru, og rodskuddet (i Vulgatas tekst flos, blomst) med hendes barn Jesus. ${ }^{30}$ Således er begge en ny vækst på Isajs gamle stub. I Luthers læsning derimod refererer både "kvisten" og "blomsten" til Jesus, mens den gamle, frønnede stub er Maria, der nedstammede fra den så godt som uddøde Davidsslægt. Af denne tørre, døde stamme springer altså det nye! I sin juleprædiken i 1520 forbindes den døde stub med Marias afdøen fra verden, hendes totale "gelassenheit", som gjorde hende modtagelig for det ny liv. I "Magnificat" understreges mere hendes ringe herkomst og lave selvværd. Fokus er ikke Maria, men Gud, som ser ned til det lave og hvis store gerninger finder sted i de uslest tænkelige rammer. Hvad der berømmes ved Maria, er den jubel og lovsang, disse gerninger ved Åndens kraft vækker i hende.

1523 fejres Marias moderskab i en protestantisk læsning, der understreger Guds handlen og Marias på alle måder menneskelige væsen.

Primo depingenda est nobis historia in se, ut nos gereitzet werden cum gaudio ad hanc nativitatem, quia maiestas, mirum est, dei se emittit in uterum feminae, quae est minor viro, ... Honora matrem, ita tamen ut consyderes, quod et ipsa caro et sanguis est, obnoxia omnibus malis und auch nit allerley reyn \&c.. (WA 11,217). (Først skal selve historien udmales, så at vi vækkes til glæde over denne fødsel, fordi Guds majestæt, forunderligt, har udgydt sig i en kvindes skød, (en kvinde), der oven i købet er mindre end en mand...Ær moderen, dog således at du betænker, at også hun er kød og blod, belastet af alskens dårligdomme og heller ikke så helt igennem ren...”).

Det er sønnen, der gør moderen hellig, ikke omvendt. Påfaldende er ikke desto mindre Marias vedblivende centrale placering i juleaftens udgaven af "det salige bytte". "Jeg tror ikke, der er nogen af os, der

29. Cl.A. 2, 133-186; Dansk oversættelse: Luthers Skrifter i Udvalg III, Aarhus (Aros 1980) 180-259.

30. Jf. foruden en udbredt højmiddelalderlig ikonografi Hildegard af Bingens tekster, f.eks. "O viridissima virga, aue, ...Nam in te floruit pulcher flos". Symphonia, Opera Minora, ed Peter Dronke, CC Cont.med. 226 (Turnholt :Brepols Publishers 2007) 395. 
ikke gerne vil forlade sin mor for at blive Marias barn..." (WA 11, 219) "Hvem vil ikke gerne have sådan en sød ung pige til sin mor?" (WA 29,655). Med Luthers hyppige henvisninger til visuelle fremstillinger af fødselssceneriet in mente spørger man uvilkårligt, hvor stor en rolle disse har fået lov at spille her? For det, der stilles i udsigt, er jo, at den kristne med Jesusbarnet skal "stråle som en soll i sin moders favn..."

\section{Julen og det kirkelige rum}

Med Luthers forsøg på hvert år på ny at fremstille Jesu fødsel levende og nærværende befinder vi os i det kirkelige rum, hvor det ikke gælder om at formidle noget ubekendt, men genfremstille det endog særdeles velkendte. "Historien er nem og I kender den stort set alle...", siger han og henviser til den måde, fødselsscenen er afbildet på. Det betyder naturligvis også, at han ikke først, som han hævder om Lukas, "overlader det til englen" at afsløre over for menigheden, at Guds majestæt er skjult i det nyfødte barn. Uden denne bevidsthed som forudsætning ville hans udmaling af de elendige forhold jo ikke have den tilsigtede virkning. Ganske vist er det altid tragisk, når et barn kommer til verden under kummerlige forhold, men beretningens indre spænding er dog fra starten af til stede netop som følge af tilhørernes viden om, at barnet er Gud. Dermed rykkes prædikenen hen i nærheden af det rituelle, som med Bernhard forkynder nyt for de troende gennem gentagelsen af kendte ord.

Teknisk set er Luthers juleprædikener nærmest homilier, dvs. prædikener, hvor man kommenterer teksten vers for vers. Som vi har set, fabulerer han nærmest krybbespilsagtigt over fødselshistorien, hvis detaljer han også kan omsætte i moraliseringer og letfattelige allegorier. Herefter gennemgås englens udsagn led for led, så de enkelte ord som "glæde", "jer" og "frelser" fyldes med teologisk substans.

Den gennemførte toleddede struktur giver ham desuden mulighed for at foretage en markant samordning af katekese og prædiken. $\mathrm{Hi}$ storia er her at betragte som det "stykke", der skal indarbejdes, lige som Trosbekendelsens artikler. Samme historia giver ingen mening, hvis der ikke følger en "forklaring" med. Denne baseres lige som katekismeforklaringerne til anden trosartikel på en gentagelse af det fortalte, men nu med et personligt pronomen som nøgle. Luther kræver, at disse pronominer mere end noget andet indpræges i hukommelsen. En metafor, han gerne griber til i denne sammenhæng, lader muligvis en datidig kateketisk og liturgisk praksis skinne igennem, idet man hængte den skrevne tekst op som banner på væggen i kirke, hjem eller scene. 
'Vos': illae 3 literae sunt tam magnae, ut coelum et terra non tam magnae” (WA 27, 493). (JER: disse tre bogstaver er så store, at himmel og jord ikke er så store). 'Ewr heiland' scribe magnis literis" (WA 29,655 [R]) ('JERES frelser' - skriv det med store bogstaver).

I kirkelig sammenhæng repræsenterer englene det 'indbrud' af anderledes virkelighed, som opstår med evangeliets forkyndelse. Luther betegner dem derfor som "prædikanter" og som forløbere for "min sognepræst", gennem hvem jeg 'i dag' hører ordet - det himmelske 'vobis' i al sin vælde. Englenes "liturgiske" fremtrædelsesform (lys, sang) underbygger den guddommelige autoritet, som møder menigheden i gudstjenestens prædiken. Der er ingen modsætning mellem ritual og prædiken, men hele gudstjenesten fremstår som en integreret helhed (jf. Nielsen 2004, 100).

Dette syn på prædiken og gudstjeneste var bestemt ikke enerådende i datiden! Prædikenens betydning i den senere middelalder var stor og kan næppe overvurderes, men den var ikke nødvendigvis knyttet til gudstjenesten eller kirkerummet. Den kunne fint finde sted fra en kasse udenfor. Det voluminøse og mildt sagt ikke særligt læseværdige evangelisationsarbejde, der i de førreformatoriske århundreder var udgået fra tiggermunkenes ordner, var båret af den noble overbevisning, at folket burde oplyses om Guds vilje. For at foredraget ikke skulle blive for kedeligt, indflettede man "folkelige" anekdoter, de såkaldte exempla. Her kan man virkelig skille teologien fra de "folkelige indslag"! Først med den lutherske reformation fik prædikestolen sin (hæders) plads i det fysiske kirkerum ${ }^{31}$, og prædiken og gudstjenesteliturgi indgik i den symbiose, som kendes fra den lutherske kirke i dag.

Det er således helt berettiget, når Luthers samtid betragtede den evangeliske prædiken som noget nyt, men det er også forståligt, at Luther selv så sig stående på skuldrene af den helt anderledes og liturgisk indlevede prædikenform, han havde fundet hos Bernhard af Clairvaux og Johannes Tauler.

31. Martin Wangsgaard Jürgensen, Changing Interiors: Danish village churches $c$. 1450 to 1600 (København 2011). 